\title{
Die Narratiewe terapie en die Gestalt terapie: ' $n$ Vergelyking tussen ' $n$ fenomenologiese eksistensiële benadering en ' $n$ sosiaal konstruksionistiese beskouing tot terapie
}

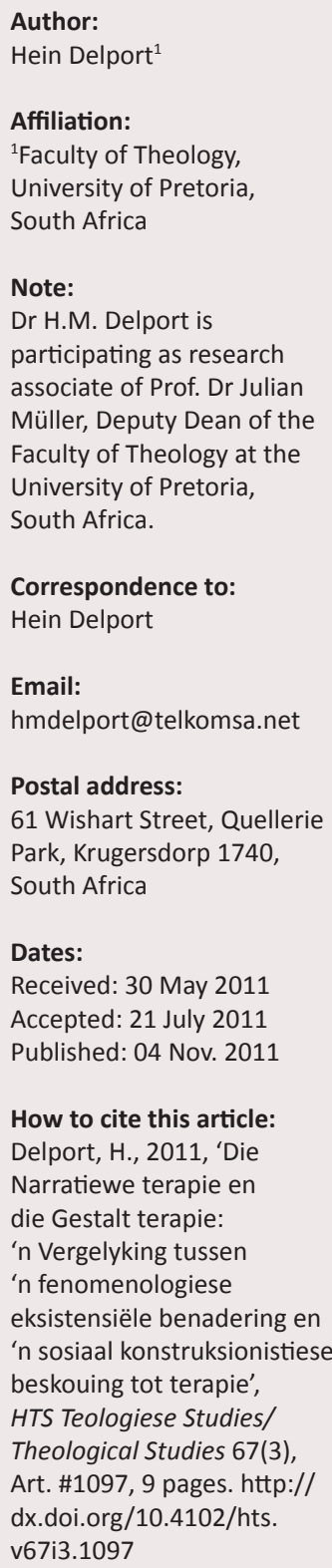

The Narrative therapy and the Gestalt therapy: A comparison between a phemenological existensial approach and a social construction approach to therapy

In this article the author takes a bird's-eye view of the background and fundamentals of the narrative therapy as well as the Gestalt therapy to show similarities between these approaches in an attempt to establish a combined or complimentary approach to therapy.

\section{Inleiding}

Deur 'n kort voëlvlug van die ontstaan en die kernbegrippe en sleutelterme van die narratiewe terapie en die Gestalt terapie te onderneem, hoop ek om vir die leser aan te toon hoe hierdie benaderings merkwaardige ooreenkomste toon. Die gemak en openheid van hierdie benaderings kan maklik gekombineer word om 'n generatiewe atmosfeer in die praktyk te bewerkstellig.

Die betekenis van die Duiste woord Gestalt kan nie maklik vertaal word nie, omrede dit so baie konsepte voorstel naamlik, die gehele vorm, patroon, konfigurasie, wat nie gebreek kan word sonder om die hele natuur van die vorm te vernietig nie. Dit stel 'n strukturele entiteit voor dat dit beide verskil van vorm en meer is as die somtotaal van al die dele.

\section{Agtergrond}

In die volgende twee punte word oorsigtelik gekyk na die ontstaan en agtergrond van invloed van die twee perspektiewe. Dit is nie moontlik om die uitgebreide etimologiese verstaan van die verskillende bewegings en definisies uiteen te sit nie, tog is dit nodig vir 'n duidelike verstaan om na die oorsprong te vra van die narratiewe sowel as die Gestalt benadering en hoe dit tot terapie ontwikkel het.

\section{Die narratiewe benadering}

Die narratiewe idee en praktyk is die eerste keer gebruik deur Michael White en David Epston teen die 19de eeu (Zimmerman \& Beaudoin 2002). White is aanvanklik beïnvloed deur die denke van Gregory Bateson wat op sy beurt weer beïnvloed is deur die familiesisteem of familieterapie teorieë (Zimmerman \& Beaudoin 2002). Die narratiewe benadering toon baie ooreenkomste met die post-struksionalistiese beskouing van Foucault. Dit verteenwoordig 'n radikale wegbeweeg van struktualisme, wat die Westerse denkrigting so geweldig beïnvloed het. Die narratiewe benadering is ook gesetel in die idees van post-moderniteit en die sosiaal konstruksionistiese diskoers. In besonder word daar gekyk na die alternatiewe verstaan van wie 'n persoon is, wat die probleem is, en hoe verandering plaasvind in die nuwe manier van dink. Volgens Zimmerman en Beaudoin, kan die volgende opsomming oor die narratiewe benadering insig bied in wat die benadering behels.

Die narratiewe benadering behels 'n uitgebreide gesprek met die gespreksgenoot waar:

- hulle ervaring (en die manier hoe dit gestalte vind in taal) die voorkeur geniet om te bepaal wat die probleem is

- vrae gevra word om die mens te help om die probleem los van die invloed van die probleemverhaal te sien

- aan ervarings, van die hede en die verlede, wat diskongruent met die probleemstorie is, aandag gegee word. Vrae word gevra na die betekenis van hierdie ervarings.

Volgens Zimmerman en Beaudoin impliseer poststrukturele denke dat daar geen ware jy is nie, geen essensiële self wat ontdek moet word of wat gesien kan word as die fondament vanwaar 
ons besluite neem en aksies uitvoer nie. ' $n$ Mens sou eerder kon sê dat ontelbare weergawes van ' $n$ identiteit bestaan, wat sosiaal en kultureel gevorm en behou word.

Volgens Müller (2000:33) word persoonlike identiteit bepaal deur gesinsidentiteit en dit word weer bepaal deur 'n wyer kultuuridentiteit. Elke gesin, familie of wyer sisteem (soos 'n kultuurgroep) het kernverhale wat daaraan ' $n$ unieke identiteit verleen. Die post-strukturalis vind betekenis in die dominante kulturele diskoers, wat gesien kan word as die diskoers wat al ons ervarings vorm. Vanuit hierdie perspektief kan individualisme gesien word as 'n diskoers wat die betekenis sentreer in die individu se belewenis. Diskoerse kan hier gesien word as die kulturele raamwerk waarin ons die wêreld beskou en waarin ons betekenis in die wêreld vind. Daar word aannames vanuit die diskoers gemaak wat die mens ervaar as die waarheid. Die mens het ervarings en die mens gee betekenis aan die ervaring wat hy of sy het. Die betekenis word gevorm deur die diskoers waarin die mens leef (Zimmerman \& Beaudoin 2002).

Volgens McCormack (2009: An Introduction to the narrative worlview) is die beskouing van die narratief ' $\mathrm{n}$ wêreldbeskouing wat die tradisionele idees van die wêreld en die beskouing van die wêreld op nuwe maniere uitdaag. In die hart van die nuwe narratiewe wêreldperspektief sien McCormack ander idees as wat as waarheid gesien kan word en waaruit die realiteit van die mens tot stand kom. Dit impliseer dat alles wat ons van die wêreld weet, alles wat ons van onsself weet en hoe ons ander mense verstaan en betekenis vorm, geensins vasstaande is nie. Volgens McCormack is die nuwe narratiewe beskouing van die wêreld dat ons die realiteite waarbinne ons leef self skep. Die narratiewe wêreldperspektief skilder ' $n$ portret van die lewe waar die lewe en waar realiteit gesien word as iets wat vloeibaar en gedurig in transitio is. Die narratiewe wêreldperspektief stel voor dat ons werklikheid - die betekenis wat ons aan die wêreld koppel - gekonstrueer word deur taal en storie. Die verhale in mense se lewens word nou gesien as ' $n$ integraal met die koppeling van betekenis in die wêreld waarbinne die mens leef. Verhale vorm die mens se waardes en betekenis in die wêreld. Die narratiewe metafoor beskryf mense as die outeurs van hulle eie lewe en die self, oftewel die mens se indentiteit. Die mens self het die keuse van watter verhale in die mens se lewe die werklikheid en die vorming van betekenis gaan beïnvloed. Volgens McCormack (2009: What is narrative therapy?) stel die narratiewe wêreldperspektief voor dat die mens se verstaan van die werklikheid nie gesien kan word as ' $n$ versameling van waarhede wat inherent in die heelal bestaan en net wag dat ons dit ontdek nie, maar dat die werklikheid sosiaal gekonstrueer word. Die mens self konstrueer sy eie werklikheid waarbinne hy of sy leef. Dit word gedoen deur die vertelling en hervertelling van verhale, oftewel stories, van die mens en die groter diskoers in die wêreld. Volgens McCormack is daar drie groot hulpmiddels vir enige narrator in die narratiewe wêreldperspektief: eksternalisering, dekonstruksie en die hervertelling van die verhaal.

\section{Die Gestalt benadering}

Die Gestalt as benadering tot terapie kan vergelyk word met 'n boom. Die wortels lê in psigoanalise en karakteranalisering, terwyl die stam beskryf kan word as femenologie en eksistensialisme, en die takke ryk uit na Oosterse filosofie en transpersoonlike verstaan. Die boom staan in 'n landskap van holisme en veldteorie wat gekombineerd vertoon. In die wese van die boom is die waardering van 'wees': physis of die elan vital [lewenskrag] (Clarkson 1999:16). Daar bestaan drie periodes in die ontwikkeling van Gestalt terapie: die voorlopers van Gestalt psigologie; die skool van Gestalt psigologie en die ontwikkeling van Gestalt psigoterapie (Bowman \& Brownell 2000). Vanuit 'n sosiologiese, historiese, filosofiese en teologiese perspektief kan die Gestalt dialektiek beskou word as 'n transformasie van die spirituele ontwikkeling van die menslike bewussyn na 'n hoër vlak van bewus wees (Vieyra 2004). Gestalt is gevestig in verskeie kreatiewe en teorietiese dissiplines wat wissel van Fisika, die Oosterse geloof, Eksistensiële Fenomenologie, Teater, Psigoanalise, Gestalt psigologie, Sisteme en Veldteorieë, Bio-energie en Ekspressiewe beweging. Die konsep van sisteme en velde kom van die vroeë 20ste eeu se fisika wat die elektromagnetiese kragte van die velde rondom objekte bestudeer het. Veldteorie is ingesluit deur ander dissiplines soos filosofie, sosiale wetenskappe en psigologie. In besonder was inname van die veld teorie deur die werk van die holistiese politikus en filosoof Jan Smuts (1939); die fisikus Goldstein (1939); Koffka (1935); Wertheimer (1925); Kohler (1970); die sosiale wetenskaplike Kurt Lewin (1926) wat die veldteorie ontwikkel het; en die bioloog Ludwig von Bertalanffy (1950) wat die sisteemteorie ontwikkel het, in die ontwikkeling van die Gestalt benadering opvallend (Mackewn 1999:14). Die teoretiese fondasies van Gestalt terapie is afkomstig van die neo-analitiese en psigoanalitiese teorieë, eksistensiële denke, fenomenologie, Oosterse filosofie en die algemene semantiese verstaan. Kohler (1925) en Kurt Koffka (1924) het begin met die ontwikkeling van die konsep van 'insig'. Perls het sy onderrig begin toe die vernaamste navorser in Europa, Freud was. Willem Reich wat deur Freud opgelei is, het Perls se onderwyser en analis geword. Alhoewel Perls met die teorieë van Freud verskil het, is hy in sy poging om homself te vestig as die vader van Gestalt psigoterapie, baie beïnvloed deur die psigoanalitiese teorie van Freud. Perls (1969) het Gestalt terapie beskryf as ' $n$ filosofie wat poog om harmonie in ewewig met alles te bewerkstelling. 'n Belangrike neo-analis in terme van die invloed op Gestalt terapie was C.G. Jung, die eerste student en kollega van Freud. Jung se analitiese teorie en die perspektief van konstruksie van polariteit het die Gestalt denke baie beïnvloed. Die Gestalt terapie het Jung se konsepte van polariteit beïnvloed met die gevolg dat daar ' $n$ idéé ontstaan het dat enige gedeelte van die self ' $n$ teenoorgestelde het, en hierdie teenoorgestelde kan gebruik word vir die ontwikkeling en die verstaan en die kennis van die self. Daar is die uitgedrukte en onuitgedrukte, die goed en die sleg, die negatief en die positief. Gestalt terapie poog om jou bewus te mak van hierdie polariteit van die menslike ervarings om die algehele ervaring en spontaniteit weer heel te maak (Hardy 1991:6, 7). 
Die Gestalt benadering het ontstaan in die eksistensiëlehumanistiese tradisie van sielkunde. Dit kan beskryf word as die derde golf van humanistiese sielkunde. Perls (1960) het Gestalt gesien as die enigste psigoterapie wat net op femenologie gebaseer is; ' $n$ sielkundige benadering gebaseer op filosofie wat wegbeweeg van konsepte na 'n totale bewuswording. Om die betekenis van ' $n$ ervaring te verstaan moet ' $n$ mens ' $n$ ervaring femenologies kan beskryf; dit word in die Gestalt nie geïnterperteer of verduidelik nie (Clarkson 1999:3, 4). In die verlede het mense 'n wanbegrip gehad van Gestalt, in die opsig dat hulle vasgehou het aan die perspektiewe van Perls en die gedagte dat Gestalt gaan oor oefeninge, tegnieke en eksperimente. In die laaste 15 jaar het Gestalt terapeute radikale stappe geneem om die oorspronklike en komplekse Gestalt perspektief te ontwikkel. 'n Teorie is ontwikkel waar intersubjektiewe verhoudings die esssensiële voertuig is vir heling en selfontwikkeling (Mackewn 1997:13).

In die 1920's is Perls veral beïnvloed deur die filosoof Friedlander se idees oor differensiële denke. Friedlander het geglo dat wat ookal bestaan, deur die mens gepolariseer kan word in twee teenoorgesteldes. Wanneer iemand vasgevang word deur een van die teenoorgestelde magte of kragte, dan veroorsaak dit 'n eensydige perspektief op die lewe en die lewe is nie meer in balans nie. Die gebalanseerde persoon bly in die homeostase van die zero middelpunt, soos in die oog van 'n tornado. Enige afwyking van die middelpunt kan as pynlik beskou word en die terugkeer na hierdie punt kan beskou word as satisfaksie. Goldstein was 'n lid van die Gestalt skool van psigologie wat gestig was deur Wertheimer (1880-1943). Hy het gedemonstreer hoe 'n besering van een kant van 'n persoon nie net die spesifieke gedeelte van die persoon beïnvloed nie, maar die totale menswees van 'n persoon. Wertheimer het Wundt weer gekritiseer vir die verduideliking van die sensoriese ervaring in terme van die elemente en persepsie van die geheel. Hy het ontdek dat wanneer ' $n$ persoon ' $n$ vertikale lyn sien en in 0.02 sekondes verder 'n horisontale lyn van dieselfde lengte, dan wil dit vir die persoon wat die lyn sien voorkom asof dit dieselfde lyn is wat van posisie geval het. Daar is vir die waarnemer 'n sin van beweging sonder inhoud, 'n ervaring wat deur Wertheimer beskryf word as die purephe fenomeen. Individue beskou hulle omgewing as ' $n$ totale eenheid van betekenis. Hulle reageer op die geheel van wat hulle kan observeer en hierdie geheel is saamgestel uit die stimuli van waarop hulle kan reageer en waarop hulle nie kan reageer nie. Hierdie manier van denke het klem gelê op die differensiasie en integrasie van die figuur en die grond (agtergrond). Koffka (1887-1941), 'n assistant van Wertheimer, het die gedagte van figuur en grond laat substansieer. 'n Uitsondering vind plaas wanneer die visuele veld ongedifferensieer is, soos in die geval van intense vog in die lug. Die hipotese in Gestalt is dat die objek die fokus van die persoon word, wat dan in die agtergrond verplaas word deurdat ' $n$ ander objek nou die voorgrond in die persoon se lewe word. Wanneer die ineenvloei van die proses figuur en/of grond versteur word, lei hierdie interaksies tot ' $\mathrm{n}$ opstapeling van onvoltooide gestalts. Die Gestalt sielkunde postuleer 'n prinsipe van afgehandelheid, waar ' $n$ persoon daarna streef om ' $n$ voltooide figuur te visualiseer en dit dan te beskou in sy geheel. Perls was baie beïnvloed deur eksistensialisme in die ontwikkeling van Gestalt terapie. Perls (1969) het geglo dat Gestalt een van drie terapieë is wat gebruik gemaak het van die eksistensialistiese prinsipes; die ander was Frankl se logoterapie en Binswanger se dasein terapie. Die grootste bydrae wat die eksistensialisme tot die Gestalt gemaak het was die konsepte van persoonlike verantwoordelikheid, die teenswoordige moment en bewuswording. Eksistensialisme het beklemtoon dat individue verantwoordelik is vir hulle eie bestaan. Die invloed kan gesien word in Perls se definisie van volwassewording (maturation) as die transendensie van omgewing na self-afhanklikheid (O’Leary 1992:5, 6).

\section{Grondbegrippe en kernwaardes Narratiewe terapie Die narratiewe wêreldbeskouing en realiteit}

Ek stem saam met Steyn en Van den Berg (2005:737) dat die narratiewe benadering nie net gesien kan word as ' $n$ metode nie, maar ook as 'n paradigma. Elke mens se storie is deel van God se narratief. Die mens se verhaal kan nie verstaan word sonder om te kyk na die volle prentjie waarin die mens saam met God stap nie.

Binne die paradigma van 'n postmoderne wêreldbeeld noem Freedman en Combs dat daar sekere idees is wat ' $n$ defnitiewe invloed het op die werklikheid of die realiteit van die mens (1996:22-35). Realiteit word sosiaal gekonstrueer. Mense konstrueer self hulle werklikhede soos wat hulle dit uitleef. Realiteite word gekonstitueer deur taal. Binne die moderne wêreldbeeld is daar ' $n$ duidelike onderskeid tussen die objektiewe wêreld en die subjektiewe wêreld van die mens. Taal kan gesien word as ' $n$ nuttige hulpmiddel wat die twee wêrelde van die mens verbind. Die postmoderne wêreldbeeld sien dit anders. Hier word daar gefokus op taal as konstruerende middel waarmee die mens sy of haar perspektief op realiteit konstrueer. Vir die postmodernis is die enigste wêrelde wat die mens kan ken die wêreld wat mense deel deur taal. Taal word dus gesien as ' $n$ interaktiewe proses en nie ' $n$ passiewe proses nie. Realiteite word georganiseer en onderhou deur stories. White (1991), soos aangehaal deur Freedman en Combs (1996:32), beskryf die kulturele verhale van mense as die verhale wat die individuele lewensverhale van mense vorm. In enige kultuur is daar verhale wat as dominant teenoor ander narratiewe beskryf kan word. Hierdie dominante narratiewe sal die voorkeur en toepaslike manier van optrede in daardie kultuur beskryf. Daar is geen essensiële waarhede nie. In die narratiewe en sosiaal-konstruksionistiese wêreldbeskouing kan 'n mens nie realiteit objektief waarneem nie; al wat gedoen kan word, is om ervarings te interperteer. Daar is baie maniere van interpertasie van enige ervaring, maar geen interpertasie kan gesien word as die essensiële waarheid nie. Daar is ook geen essensiële self nie, daar is wel 'n voorkeur self wat voorgestel word deur 'n spesifieke konteks of kultuur waarbinne die mens leef. Sosiale werklikhede is dalk in essensie nie die enigste waarheid nie, maar tog het die uitwerking daarvan op die mens 'n ware effek. White (aangehaal deur Freeman 
\& Combs 1996:39) skryf dat die mens geneig is om die dominante narratiewe te internaliseer. Dit veroorsaak dat dit deur die mens self beskou word as die waarheid oor sy of haar eie identiteit. Dit is duidelik dat dominante narratiewe die mens maklik kan verblind en weerhou daarvan om enige ander narratiewe te sien of te hoor.

Stories (narratiewe) benodig luisteraars sowel as vertellers. Deur middel van die sosiale praktyk van die vertel en hervertel van stories verkry dit genoeg substansie om mense se lewens te verander. Ons word in stories in gebore en hierdie stories werk vormend in op ons persepsies van wat moontlik is. Ons dink egter gewoonlik nie aan hierdie stories waarin ons gebore word as stories nie, maar eerder as werklikheid. Op hierdie wyse vorm stories ons ervaring van die werklikheid.

\section{Die ervaring van tyd}

Sarbin (1986), soos aangehaal deur Burr (1995:134), noem dat die mens sy of haar ervaringe struktureer en dat hierdie struktuur teenwoordig is wanneer daar na die self en na ander se ervaring en die mens se verhouding met ander gekyk word. Hierdie struktuur noem hy die narratiewe struktuur. Die mens organiseer sy of haar ervaring in terme van verhale. Dit suggereer glad nie dat die mens in 'n sprokieswêreld leef nie. Sarbin sien hierdie strukturering in die narratiewe as ' $n$ gegewe by enige mens se samestelling of konstruksie van die self. Die narratief is teenwoordig in die mens se drome, in die herinnering van die mens, in die planne vir die toekoms en selfs in die manier hoe die mens ' $n$ gebeurtenis aan iemand anders oorvertel. Daar is in hierdie prosesse nie slegs ' $n$ beskrywing oftewel resitering van feite nie, maar eerder ' $n$ storie met ' $n$ begin, ' $n$ middel en ' $n$ einde.

Dreyer (2003:348) noem dat die karakters in die verhaal 'n identiteit kry, 'n persoonlike integriteit. Die karakter bly aan die een kant dieselfde van die begin tot aan die einde van die verhaal. Aan die ander kant verander die karakter in reaksie op gebeurtenisse. Die plot hou die reeks gebeurtenisse en reaksies bymekaar in ' $n$ sinvolle geheel. Die verhouding tot tyd maak dit moontlik om raakpunte te identifiseer tussen gebeurtenisse. Die plot vorm die eenheid ten opsigte van die verhaal en die karakters. Die plot word weer gebou deur middel van die optrede en/of reaksies van die karakters in die verhaal. Die verskeidenheid van karakters en hulle narratiewe funksies bied die leser of die hoorder die geleentheid om te ervaar hoe die karakters optree. Die leser of hoorder se betrokkenheid by die storie open die moontlikheid om in hulle eie lewe 'agent' (nie slagoffer nie) te wees in die simmetriese subjek-subjek interaksie met ander.

Wanneer ek ' $n$ verhaal in my lewe aan iemand anders oorvertel, onthou ek nie die hele inhoud van die ervaring of gebeurtenis tot op datum nie. Die mens is selektief in hul keuse met betrekking tot wat bygevoeg word in sy of haar verhaal van die lewe. Wat ingesluit en uitgesluit word in die oorvertel van 'n verhaal is die keuse van die narrator. Elke mens vorm sy of haar eie verhaal ten opsigte van ' $n$ tema; byvoorbeeld die lewe as 'n avontuur, 'n komedie of 'n tragedie, ensovoorts (Burr 1995:135). Dit is betekenisvol om aan die struktuur van die narratief te dink as die manier waarop die mens sy of haar lewe uitleef, asook op die manier waarop die mens sy of haar lewe in privaatheid of in die publiek oorvertel. Die konsepte van tyd en ruimte is volgens Sarbin (soos aangehaal deur Burr 1995:135) fundamenteel vir die mens in die opsig dat die narratief nie daarsonder kan plaasvind nie.

\section{Eksternalisering en ' $n$ alternatiewe verhaal}

Narrative therapists are interested in discovering, acknowledging and taking apart (deconstructing) the beliefs, ideas and practices of the broader culture in which a person lives that are serving to assist the problem and the problem story.

(Morgan 2000:45)

Dit is belangrik dat ' $\mathrm{n}$ terapeut die persoon se identiteit losmaak van die probleem. Die probleem is die probleem, nie die persoon nie (Morgan 2000:17).

Volgens Micheal White (1989:5) wat die metode van eksternalisering ontwikkel het, moet mense gehelp word om aan die probleem te dink as iets wat buite hulleself is. Die probleem word dus geobjektifiseer en gepersonifieer deur dit buite jouself te plaas. Wanneer daar met jong kinders gewerk word, kan die probleem gepersonifieer word deur dit 'n naam te gee en dit visueel voor te stel deur dit te teken of deur enige ander nie-verbale manier van uitdrukking. Die spesifieke beskrywing van die ge-eksternaliseerde probleem moet egter die mede-navorser se eie taal of uitdrukking van sy of haar ervaring wees.

Ge-eksternaliseerde beskrywings ontwikkel dikwels gedurende die verloop van terapie. Die probleem, die effek(te) van die probleem, probleemverhale of dit wat geglo word, patrone van interaksies, kulturele verwagtinge, en praktyke wat die probleemverhale ondersteun, is alles moontlikhede wat ge-eksternaliseer word. Wanneer 'n probleem ge-eksternaliseer is en ' $n$ ander naam daaraan gegee is en dit losgemaak is van die persoon se identiteit, vra die terapeut gewoonlik vrae aangaande die geskiedenis van die probleem in die persoon se lewe. So word daar gepoog om die invloed van die probleem in 'n persoon se lewe oor 'n lang periode te ondersoek (Morgan 2000:33).

Müller (1998:70) noem dat die narratiewe terapeut eintlik net drie belangrike hulpmiddels het waardeur hy die verhale van mense ernstig kan opneem en waarmee daar saam met die gespreksgenote op reis gegaan kan word. Deur responsaktief te luister, met 'n nie-wetende houding, en deur gespreksvrae, kan die terapeut narratief betrokke wees by die gespreksgenoot se verhale.

Vir Müller (2000:72) moet 'n model in die paradigma van die narratief nie as bewegings beskou word waar stappe of fases voorkom nie. Dit kan eerder as 'n dans-model gesien word, as wat daarna verwys word as ' $n$ strategiese model. Die klem val eerder op die sirkulariteit as op ' $n$ liniêre beweging. Die terapeut, of navorser, of gespreksgenoot, se taak is om vyf groot bewegings uit te voer. 
Help die gespreksgenoot om die storie van nood so goed moontlik te vertel: die noodverhaal. Laat die mede-navorser toe om die verledeverhaal te vertel. Ontdek saam met die gesprekgenoot die toekomsstorie in die verledeverhaal. Dit is die toekomsverhaal. Die verledeverhaal moet geherinterpreteer word. Dit behels die proses van reframing. Deur ander temas in plaas van die probleem-versadigde temas te suggereer, nooi ons mense uit om te begin skep aan nuwe verhale oor die verlede. Dit is die hervertelde verledeverhaal. Die herinterpretasie van die verlede word vanself ' $n$ uitnodiging om ' $\mathrm{n}$ beter toekoms meer effektief te verbeeld. Dit is die verbeelde toekomsverhaal (Müller 2000:72, 73).

'n Metode om die interpretasie van die verskillende verhale te laat ontwikkel in ' $n$ hervertelde verhaal, is die metode van backtracking en looping. Om die verledeverhaal te vertel kan vergelyk word met backtracking. Wanneer looping bykom, is dit soos wanneer die vervolgde daarin slaag om die agtervolger te ontduik en agter sy rug begin om hom te volg. Dit is as 't ware om jouself te agtervolg, om op jou eie spore terug te loop en jou eie weg opnuut te probeer verstaan (Müller 2000:93).

Dit is baie duidelik dat in die alternatiewe verstaan die uitdaging daar is dat die werklikheid van die navorser sowel as die mede-navorsers uitgedaag word deurdat die relevansie op nuwe maniere tussen sake geplaas word. Sekerlik die grootste uitdaging lê daarin opgesluit om die relevansie tussen die negatiewe van die verledeverhale en die positiewe van die toekomsverhale te ontdek.

Dit is maklik vir die terapeut om as gevolg van die problem saturated story enige positiewe uitkomste mis te kyk:

As therapists discover unique outcomes they are interested in exploring them further, tracing their history and understanding what they mean to the person concerned. Unique outcomes are the doorways or openings to new and different stories.

(Morgan 2000:59)

'The alternative story is usually "anti-problem" and brings forth people's skills, abilities, competencies and commitments' (Morgan 2000:59).

Sekere landscape of action en landscape of identity vrae is in die gesprek by opsporing van die geskiedenis van die probleem, verweef. Indien die dominante storie later weer sou terugkeer, sal hierdie eienskappe die persoon help om die gekonstrueerde werklikheid te onthou (Morgan 2000:68). Die vertel en hervertel van hierdie ervarings maak die nuwe storie ryker en voller. Vrae soos wanneer, waar en hoe dit ontwikkel het, ensovoorts, kan help om hierdie proses te fasiliteer. Michael White (in Zimmerman \& Beaudoin 2002:35) verwys hierna as 'landscape of action questions'. Die 'waarom?' kan ook aangespreek word, hierna word verwys as landscape of identity questions. Volgens Zimmerman en Beaudoin (2002:35) sluit vrae aangaande identiteit, vrae in oor die betekenis van unieke uitkomste en wat die unieke uitkomste oor die persoon se motiverings, waardes en identiteit sê.

\section{Gestalt terapie}

Clarkson (1999:30) beskou die volgende as grondbeginsels in die Gestalt terapie: Gestalt terapie is fenomenologies; die enigste doel is bewuswording en die metodologie is die metodologie van bewuswording. Gestalt is totaal gebaseer op 'n dialogiese eksistensialisme, die I-Thou kontak of terugtrekking. Gestalt terapie se konseptuele fondasie of wêreldsperspektief in die Gestalt is gebaseer op holisme en veldteorie. Williams (2006:8) beskou die doelwitte van die Gestalt terapie as groei, bewuswording, kreatiwiteit en integrasie.

\section{'n Gestalt wêreldbeskouing en realiteit}

Wanneer die mens aanleer om sy of haar verhaal anders te vertel, dan kan hy of sy hulle werklikheid ten opsigte van die subjektiewe ervaring van werklikheid verander. Ons sou ook kon sê dat wanneer ons ons subjektiewe ervaring van werklikheid verander, ons ons lewensverhaal verander. Gestalt deel die gedagte met fenomenologie dat dit nie moontlik is om 'n enkele objektief of absolute waarheid te identifiseer nie, maar net om 'n meervoudige van subjektiewe interpertasies van die realiteit te open, want elke ervaring kan beskou word as 'n unieke interpertasie van die realiteit, wat aan mense met individuele indrukke van situasies, hulle eie betekenis van gebeure gee. Die fenomenologiese metode bied die mens ' $n$ praktiese metode om jou eie beperkte perspektiewe eenkant te plaas en jouself oop te stel vir 'n wye verskeidenheid van altenatiewe perspektiewe van die intersubjektiewe veld. Daar is nie een objektiewe waarheid nie, net ' $n$ meervoudige van subjektiewe perspektiewe wat bestaan. Die doel is om soveel moontlik van die aspekte van die numeriese waarneembare moontlikhede daar te stel en om daardeur ' $n$ meer aanvaarbare persepie van die algehele relasionele situasie te bekom. Die fenomenologiese benadering is op soek na die aktuele geleefde ervaring, om die beliggaming van die natuur van die persepsie te ontbloot. Gestalt se teorie van verandering staan bekend as die paradoksale teorie van verandering juis omdat dit gebaseer is op die paradoksale veronderstelling dat mense kan verander deur al meer ten volle hulleself te word en nie om iemand anders te probeer wees nie. Die stigters van die Gestalt het voorgestel dat die self nie gesien kan word as 'n struktuur nie, maar as ' $n$ veranderende proses. Die self verander met die ontmoeting van verskillende mense en dinge waarmee dit in aanraking kom en in die altyd-veranderende veld waarin die self bestaan. Die self kan beskou word as intersubjektief: dit is die proses van kontak en assimilering van ervarings met ander aspekte van mense in verhouding. Ons ontdek en vind uit wie ons is in verhouding met ander mense. Die 'ek' bestaan in kontras met die 'jy' of die 'dit'. 'n Positiewe implikasie van die self is dat mense nie vooraf bepalend is nie, maar dat hulleself kies of hulle is vry om te kies in die moment-tot-moment moontlikhede: die mense konstrueer hulleself en die betekenis wat hulle aan hulle lewens gee (Mackewn 1997:57-74).

\section{Bewuswording en kontak}

In die Gestalt benadering kan bewuswording beskou word as die holistiese proses van kontak met, en onttrekking van, 
die ander in die veld, van selfregulasie na betekenisvorming wat plaasvind in die persoon in geheel. Dit bevestig dat ons 'is of bestaan' ons verander. Bewuswording is die manier waarop ons onsself en ons behoeftes verstaan en ook die manier hoe die mens sy veld organiseer en betekenis vind in sy ervarings (Mackewn 1997:113). Kontak lê in die hart van Gestalt terapie. Die ontmoetingsplek van individue staan bekend as die kontakgrens. Die gesonde individu besef dat hulle verskil van die omgewing en kan eenheid waag sonder om bewuswording van interne en eksterne toestande te vrees. Polster (1987) beskryf drie tipes kontak: interne, interpersoonlike en internasionale kontak (O'Leary 1992:29, 30). Perls beskryf vyf vorms van lae wat ontdek kan word voordat die finale kontakfase bereik kan word. Die eerste laag kan beskou word as die 'cliché'-laag en verteenwoordig die oppervlakkige verwisseling van betekenis en groet. Die tweede laag kan beskou word as die spel-laag, of die as-iflaag, en word gekenmerk deur speletjies en rolle. Wanneer hierdie laag verwyder word, ervaar mense die derde laag, naamlik die impasse, waar mense die vrees ontwikkel om vasgevang te word of om leeg te wees. Die vierde laag word beskou as die implosiewe laag van die mens. Dit word voorgestel as dood of vrees vir die dood. Die laaste laag van die self wat dikwels bereik word na die terapie kan beskou word as die eksplosiewe laag (Clarkson 1999:124, 125).

Meeste van die literatuur oor Gestalt fokus op die persoontot-persoon verhouding van die navorsing van Martin Buber (Harris 2000:5). Die sentrale fokus in Gestalt terapie is die oomblik-tot-oomblik proses in die verhouding tussen die gespreksgenote. Hierdie ontmoeting word gekenmerk deur die dialoog. Buber beskryf dit as die I-Thou verhouding. Dit is die ware ontmoeting tussen twee mense waar albei respek betoon vir die essensiële menswees van die ander. Die Gestalt benadering is gebaseer op die absolute onskeibare eenheid van liggaamlike ervaring, taal, denke en optrede. Wanneer daar ' $n$ grens en kontak bestaan, is dit in soverre die self se kreatiwiteit van die self. Gestalt maak die dialoog tussen twee mense in groei die sentrale helende element. Dit beteken dat tegnieke tweede plek inneem en die terapeutiese verhouding sentraal staan. Aangesien Gestalt terapeute 'n transpirante rol moet vervul, kan hulle hulleself nie beskou as die experts in die situasie nie en hulle kan ook nie 'n objektiewe rol in die dialoog inneem nie. Diagnose speel geen rol in die Gestalt benadering nie. Om mense te etiketteer neem die betekenis wat mense aan hulle holistiese ervaring van die self gee, weg.

Die Gestalt is gebaseer op die veronderstelling dat elke mens verantwoordelikheid in sy of haar eie lewe neem. Perls het dit tot die uiterste geneem met die Gestalt gebed:

I do my thing and you do your thing. I am not in this world to live up to your expectations - And you are not in this world tot live up to mine, You are you and I am I, If by change we find each other, it's beautiful. If not, it can't be helped.

(Perls, Hefferline \& Goodman 1974:n.p.)

Moderne Gestalt psigoterapie het verby hierdie hedonistiese Perlse beskouing beweeg. Gestalt is gebaseer op die gedagte dat inhoud aan konteks behoort. Geen self kan losgemaak word van die omgewing nie (Clarkson 1999:18-27). Die verhouding is net so belangrik of selfs meer belangrik as die tegniek (Noyce 1978).

\section{Figuur en/of grond}

Die mens kan beskou word as ' $n$ eenheid waarvan daar baie onderdele is wat in verhouding met mekaar funksioneer. Gesonde funksionering verwag ' $n$ vloeibaarheid van die prosesse wat figuur en grond voorstel in die persepsie van die mens. ' $n$ Veronderstelling wat die figuur enof grond gedagte voorafgaan, is dat die individu in staat moet wees om te differensieer tussen meer prominente en minder prominente stimuli in die omgewing ter enige tyd. ' $n$ Persoon moet buigsaam wees in die interaksie met die omgewing. Deur bewus te raak van die innerlike ervaring word die individu bewus van die behoefte van die voorgrond, of figuur teen die agtergrond, van sy of haar totale persoonlikheid. In die gesonde funksionering kan die individu differensieer wat noodsaaklik is en wat nie. Soos wat die behoefte toeneem word die persoon met opwinding gevul. Die opgewondenheid aktiveer die individu om hierdie behoefte te vervul. Geen een behoefte kan die figuur teen die agtergrond word nie. Wanneer die figuur dood en kleurloos bly, is daar weerstand vanaf die omgewing of een of ander behoefte van die persoon wat nie uitgedruk word nie (O'Leary 1992:10, 11).

Die toonbeeld van spontane aandag en konsentrasie is die progressiewe vorming van 'n figuur en/of grond. Die helderheid en die duidelikheid van die figuur is die energie van opgewondenheid wat dit van die agtergrond skei. Die vloei in die verhouding van die figuur en die gronde kan versteur word op twee maniere: (1) die figuur kan so gevestig word dat geen ander perspektief toegelaat word van die gronde nie en (2) die agtergrond kan te veel belangstelling genereer, waar dit onderdruk of geïgnoreer word sodat die figuur nie sigbaar kan word nie. Dit is nodig dat die terapeut definitiewe konteks identifiseer waar daar meer speling moontlik is tussen die figuur en die agtergrond. Dit kan beskou word as die eksperimentele omgewing van die gesprek of die dialoog. Wanneer spontaan aandag gegee word aan die objek, sodat dit op die voorgrond uitstaan, vervaag die agtergrond. Dan word die objek in 'n groter mate beskou as 'n eenheid met detail. Beskou die voorbeeld van 'n skildery. Hoe meer na die skildery gekyk word, hoe meer word ' $n$ mens deel van die konstruktiewe vreugde van die skilder, tot op 'n punt waar 'n mens kontak maak met die skildery: 'n 'AHA'-moment. Dit kan beskou word as 'n uitmekaarhaal en weer-aanmekaar-voeg proses: 'n aggressiewe dekonstruksie en rekonstruksie (Perls, Hefferline \& Goodman 1974:85-97).

\section{'n Gesonde en ongesonde siklus}

Perls (1969) was oortuig dat die gesonde individu funksioneer binne ' $n$ bepaalde balans met al sy of haar onderdele. Hierdie balans moet gehandhaaf word en is belangrik vir die oorlewing van die mens. Dit is die beginsel van homeostase. Daar is ' $n$ inherente drang in die mens om hierdie ekwilibrium te behou sodat groei en ontwikkeling kan plaasvind en die individu sy of haar volle potensiaal kan 
bereik; mense doen dit deur die gevoelens en ervarings wat binne hulle plaasvind te aanvaar. Perls (1969) het genoem dat die mens hierdie balans terugkry deur die behoeftes wat hulle het, te vernietig of na die agtergrond te skuif, of om daaraan vervulling te gee. Die proses noem hy die organismiese selfregulasie. Wanneer 'n aspek van die self waargeneem word, dan is die teenwoordigheid van sy ander (teenoorgestelde) implisiet. Hier word na ' $n$ balans gestreef om hierdie polêre agtergronde met mekaar te kan versoen. Perls (1969) was oortuig daarvan dat die individu ten volle bewus moet word om te kan reageer op hulle behoeftes. Hy het gesê dat bewuswording die enigste basis van kennis en kommunikasie is. Daar bestaan volgens hom drie vorme van bewuswording: bewuswording van die self, bewuswording van die wêreld en bewuswording van die tussen-in. Bewuswording omvat die totale self en fokus op die figuur. Dit stel nie belang in die onderbewussyn nie, maar in die oppervlak - die voor die handliggende. Onafgehandelde sake in die verlede neem die energie van die organisme en strem die motivering om deel te neem aan aktiwiteite. Die hoofdoel van Gestalt terapie kan gesien word as persoonlike verantwoordelikheid en die bereiking van hierdie self-regulasie (O'Leary 1992:12-18).

Enige element van die lewe kan as gesond beskou word wanneer dit die Gestalt formulasie-dekonstruksie-reformasie proses implimenteer. Wanneer enige element hierdie proses blokkeer of onderbreek, kan hierdie negatiewe invloed, wat dit ookal mag wees as ongesond vir die organisme beskou word (Hardy 1991:8).

\section{Clarkson et al. (1999) beskryf hierdie proses soos volg:}

- Ontrekking: organisme rustend.

- Sensasie: voor-kontak.

- Bewuswording: van sosiale of biologiese behoefte; voorkontak fase.

- Mobilisering: 'n opwinding fase van kontak.

- Aksie: keuse van die implimentering van die regte aksie in die kontak.

- Finale kontak: vol lewe.

- Satisfaksie: of post-kontak en Gestalt afhandeling.

Die gedagte van onvoltooide besigheid is die basis waarmee die Gestalt benadering beskryf hoe energie geblokkeer of versteur word. 'n Gevestigde Gestalt is 'n repitisie van vasgestelde optrede van patrone in die verhouding van die mense tot die omgewing en tot ander mense. Dit kan beskryf word as gevestigde patrone wat inmeng met die gesonde funksionering van die kreatiewe self op die grens van kontak met die organisme of die omgewing. In Gestalt word dit ook gesien as selfregulerende aksie, en sluit defensiewe funksies in. Perls het klem gelê op samevloeiing (confluence), introjeksie (introjections), projeksie (projection) en retrofleksie (retroflection) as die meeste aksies van die mens wat die siklus van die mens inhibeer. Goodman het ook egoïsme genoem en Polster het defleksie daarby gevoeg. Perls gebruik verder desensitisasie (desensitation). Die funksie van hierdie prosesse kan gesien word as gekonnekteerd en verweefd met mekaar (Clarkson 1999:48-51).
Desensitisasie (minimisering sensasie): In die proses is die neurotiese ervaring dat die persoon nie die omgewing kan ervaar nie. Die self voel dood of verlam. Dit is waar die sensasies en die emosies van die self ontken of verwar word of selfs verinneweer word.

Defleksie (vermyding van sensasie of betekenisvolle impak): Defleksie beteken om van direkte kontak weg te beweeg na betekenisvolle kontakmaking. Dit is 'n manier om iemand se bewuswording of (impak) van die omgewing te reduseer, deur dit vaag of algemeen te laat vertoon. Defleksie kan enige aspek van die helende siklus beïnvloed, maar veral die persoon se bewuswording.

Introjeksie (beheer deur geïnternaliseerde 'moets' en 'moenies'): Introjeksie kan gesien word as die inisiële meganisme waarmee ons voedsel, gedagtes, denke, idees inneem en beheer van ander in ons direkte omgewing. In die proses kan 'n neurotiese benadering gesien word waar die persoon die integering as normaal beskou terwyl die self die integrasie wil uitspuug.

Projeksie (om in ander te sien wat ek nie in myself wil voorstel nie): Die projektor (persoon) is nie bewus daarvan dat hy of sy ander afkeur nie en glo dat dit ander is wat die projektor afkeur. Projeksie kan baie normaal en gesond gebruik word in konstruktiewe metodes in die terapie. Wanneer daar met projeksie in die terapie gewerk word, word dit beskou as deel van die verbeelding van die persoon.

Retrofleksie (om aan myself te doen wat ek aan ander wil doen): Retrofleksie beteken om skerp terug te draai na die self.

Egoïsme (om die spontaniteit te blokkeer met beheer): Egoïsme in Gestalt word gekarakteriseer met die idividu wat buite homself tree en wat ' $n$ waarnemer word of ' $n$ kommentator oor homself en sy verhouding met die omgewing. Die neurotiese beskouing hiervan is dat die persoon bewus is en van alles iets weet, maar wanneer die persoon oor homself moet praat, is dit leeg en niksseggend.

Samevloeiing (versteuring van nabyheid): is die kondisie waar die organisme en die omgewing nie gedifferensieer kan word nie. Twee mense se sienings, optredes, en gevoelens vloei ineen sonder dat die grense tussen hulle in aanmerking geneem word en hulle mekaar se verskille kan respekteer. In alle mense moet daar ' $n$ gesonde balans wees tussen samevloeiing en die grensontwikkeling en grensbeskerming. Die permanente samevloeiing van die mens met die 'ander', hetsy persoon of situasie, lei na verlorendheid van die self en versteuring van die satisfaksie in die finale kontaksiklus (Clarkson 1999:62).

\section{Maturasie en oriëntasie van die self}

Maturasie is 'n voortdurende proses waar die individu homself of haarself transendeer vanuit die omgewing se afhanklikheid en 'n ontwikkeling van onafhanklikheid, wat ' $n$ toenemende reduksie van die afhanklikheid veroorsaak 
(Perls, Hefferline \& Goodman 1974:9). Wanneer die mens die verantwoordelikheid vir sy of haar lewe neem, is dit die eerste stap na volwassewording van die mens (Prochaska \& Norcross 2007:183). In die Gestalt terapie kan maturasie gesien word as die beweging van die omgewingsondersteuning na die selfondersteuning van die organisme. Die manier om dit te bewerkstellig is vir die mens om al meer homself te word. Van de Riet (1980) het verduidelik dat wanneer ' $n$ arend meer en meer poog om soos 'n olifant te wees, byvoorbeeld deur ' $n$ dik vel te ontwikkel en om op te tree soos wat ' $n$ olifant optree, word die arend al minder ' $n$ arend. Wanneer die mens se kontak met die omgewing versteur word, dan ervaar die mens ' $n$ kontak-grensversteuring. Die mens se predisposisie om na 'n spesifieke rigting te beweeg eerder as om rond te val in verskeie rigtings is al voorgestel deur die wet van Pragnanz. Hierdie wet verteenwoordig die menslike organisme wat probeer om terug te keer na 'n gebalanseerde staat wanneer hy van balans af is. Hierdie wanbalans kan gesien word as emosionele stres, geleerdheid behoefte of 'n ander psigologiese effek. Perls het op hierdie wet gefokus om te wys hoedat dit direk op die menslike emosies van toepassing gemaak kan word. In Gestalt terapie kan alles beskou word as proses of in proses. Die rivier verander konstant (Hardy 1991:9-28).

Van die idividu word verwag om ingenieur van die self te word. Basiese veronderstellings behels dat die terapeut die gespreksgenoot help om bewus te raak van hoe hy of sy funksioneer as 'n organisme en 'n persoon. Die Gestalt ontken die onafhanklikheid van die status van gedagtes, liggaam en eksterne wêreld. Self-regulering word van die self verwag en van niemand anders nie. Die probleem lê in die feit dat die mens homself of haarself differensieer in verskeie pole. Die subjek-objek beskouing van die mens kan gemaak word na 'n valse dikotomie. Die gedagte en siening is dat die mens aktief is, en nie passief nie, wanneer dit lewe behels (Perls, Hefferline \& Goodman 1974:35-47).

\section{Ervaring van tyd}

Die teenswoordige tyd word in die Gestalt benadering beklemtoon, wat die moontlikheid daarstel dat die verlede verken kan word by wyse van die skepping van ' $n$ werklikheid en eksistensie in die hede. Daar is ' $n$ aaneenlopende interaksie tussen drie dimensies van tyd: die verlede, die hede en die toekoms. Die verlede word uitgedruk met die ontwikkeling van 'n gegewe responsstyl wat gebaseer is op die toevoeging van verlede ervarings, 'onafgehandelde besigheid', in die teenswoordige tyd van die hede, in die hier en die nou. Die teenswoordige tyd is die arena waarbinne die die interaksie uitgedruk word. Die optrede van die mens word ook buitengewoon beïnvloed word deur 'onbeginde besigheid' wat moontlik kan, of nie kan nie, plaasvind in die toekoms. Die toekoms is deel van die lewe wat nog nie plaasgevind het nie. Die bedreiging van onvoorsiene gebeure wat nie geïntegreer kan word met die hier en nou nie, kan beskou word as faktore waaroor die mens geen beheer het nie; dit lei tot ' $n$ sekere mate van angs in die hede (Serok 2000:4-13). Gestalt terapie soek na die mens se bewuswording in die hede. Bewuswording in die hede kan gesien word as helend juis omdat so ' $\mathrm{n}$ bewuswording weer die patroon wat versteur was, kan invul (Ridgway 2007:8). Alhoewel Gestalt terapie in die besonder aandag gee aan die ontwikkeling van bewuswording en wat op die oomblik hier en nou gebeur, beteken dit nie dat die benadering die belangrikheid van die verlede en toekoms agterweë laat nie. Dit stel eenvoudig net dat mense die verlede onthou en die toekoms beplan in die hede (Mackewn 1997:118). Polster (1987) noem dat die verhaal 'n aktiewe organisatoriese agent is; dit selekteer ' $n$ paar gebeure van baie wat gebeur het en gee aan dit koherensie in die teenwoordige tyd ( $\mathrm{O}^{\prime}$ Leary 1992:36).

Die mens moet weer leer wat dit beteken om in die teenswoordige tyd te leef. Die mens is altyd besig in die hier en nou, om weer van vooraf te bou en van vooraf te leer en te vorm. Aktualiteit soos wat ' $n$ mens dit ervaar, is sy of haar aktualiteit. 'n Groot vraag in die Gestalt eksperimente gaan oor watter probleme of vertragings die mens ervaar om hierdie bewuswording te beleef. Dit gaan in die Gestalt nie daaroor om soos die kubernetika die robot al meer en meer soos ' $n$ mens te maak, of soos in ander terapieë om die mens al meer en meer soos ' $n$ robot te maak nie, maar eerder oor die optimale funksionering van die mens. Die metode van Gestalt is nie om die ambisie of die gevoel van 'n verlede te koester nie, maar eerder in terme van die bewuswording van hoe die individu nou gestruktureerd is. Die verhouding van die verlede en die toekoms moet deurgaans in die hede geëvalueer word. ' $n$ Betekenisvolle manier is om die situasie waarin jy tans verkeer te beskryf. Wees bewus van die (1) nou en (2) die weerstand wat gebied word deur die individu. Die weerstand van die organisme kan omgeskakel word in die mees betekenisvolle bystand van die organisme. Die mees omstrede optrede kan gesien word as die motivering tot oprede, en commitment, en denke kan beskou word as ' $n$ vorm van optrede. Wat gebeur as die mens twee optredes beskou as twee verskillende pole? Wat ookal die mens is of nie is nie, die mens plaas dit in terme van ' $n$ bewuswording waar albei hierdie pole kan waar wees (Perls, Hefferline \& Goodman 1974:60-81).

\section{Gevolgtrekking}

Alhoewel die twee benaderings tot terapie vanuit verskillende dissiplines ontstaan het, kan die oplettende leser nie anders as om die ooreenkomste van die twee benaderings raak te sien nie. Beide die benaderings kan beskou word as meer as net ' $n$ terapie: eerder as ' $n$ manier hoe die mens sy of haar werklikheid konstrueer. Daar bestaan geen absolute waarheid nie, en die konstruksie van die mens se self word beskou as 'n gesamentlike poging. Die proses is ook gedurig in transitio en albei benaderings het sy unieke verduideliking van rekonstruksie van ' $n$ alternatiewe verhaal of ' $n$ ander Gestalt. Die vasgeloopte verhaal kan in dieselfde lig beskou word as die gevestigde Gestalt. 'n Generatiewe moment word beklemtoon in die narratiewe terapie met die gespreksgenoot, waar die Gestalt dit beskryf in die I-Thou verhouding.

Ek is oortuig daarvan dat hierdie twee benaderings mekaar kan komplimenteer in die pastorale aspekte van Praktiese 
Teologie. Beide omvat iets van die geheel: In die narratiewe terapie word die mens se verhaal vertel in terme van die Groter verhaal, en in die Gestalt terapie sien ons die belangrikheid van die spirituele bewussyn raak met die figuur teen die agtergrond.

Selfs die proses van self-regulasie vertel van 'n verbeelde toekomsverhaal. Die eksperimente en metodes in die Gestalt terapie kan innoverend aagewend word in die narratiewe benadering om die subjek-subjek verhouding van die benadering uit te lig en sosiale konstruksionisme aan te moedig. Bewuswordingstegnieke en versteurings van die kontakgrens kan die gespreksgenote daarop laat let dat hulle albei betrokke is in wat bekend kan staan as 'n nuwe werklikheid.

Onafgehandelde gebeure in die verlede, oftewel 'n vasgeloopte verhaal, kan weer onder die loep geneem word deur nie net tegnieke van die narratiewe terapie te gebruik nie (eksternalisering, dekonstruksie, alternatiewe verhale, reframing) maar dit kan nog meer uitgebrei word deur te kyk na die versteurende komponente in die aksie of onttrekking siklus (desensitisasie, defleksie, introjeksie, projeksie, retrofleksie, egotism en samevloeiing). Deur die teenswoordige taal te gebruik en klem te lê op die sigbare kan die onvertelde verhaal van die gesprekgenoot ook beter gehoor word.

\section{Erkenning Mededingende belange}

Die outeur verklaar dat hy geen finansiële of persoonlike verbintenis het met enige party wat hom nadelig kon beïnvloed in die skryf van hierdie artikel.

\section{Literatuurverwysings}

Bowman, C. \& Brownell, P., 2000, 'Prelude to contemporary Gestalt Therapy', Gestalt Global Corporation 4(3).

Burr, V., 1995, An Introduction to Social Constructionism, London/New York, Routledge. Clarkson, P., 1999, Gestalt counselling in Action, 2nd edn., Sage Publications, Thousand Oaks, CA/New Delhi. http://dx.doi.org/10.4324/9780203299968

Dreyer, Y., 2003, 'Luister na die storie van die kerk: Riglyne vanuit ' $n$ narratiefhermeneutiese perspektief', HTS Teologiese Studies/Theological Studies 59(2), 333-352.

Freedman, J. \& Combs, G., 1996, Narrative therapy: The social constructions of preferred realities, Norton, London.

Hardy, R.E., 1991, Gestalt psychotherapy: Concepts and demonstrations in stress, relationships, hypnosis and addiction, Charles C. Thomas Publisher, Springfield, IL.

Harris, E.S., 2000, 'God, Buber, and the Practice of Gestalt Therapy', Gestalt Journal 23(1), Spring.

McCormack, M., 2009, An Introduction to the Narrative Worldview, viewed May 2011 from www.storygrounds.co.za

McCormack, M., 2009, What is Narrative Therapy? A Brief Introduction, viewed May 2011, from www.storygrounds.co.za

Mackewn J., 1997, Developing Gestalt counselling: A field theoretical and relationa model of contemporary Gestalt counselling and psychotherapy, Sage Publications Ltd, Thousand Oaks, CA.

Morgan, A., 2000, What is narrative therapy? An easy-to-read introduction, Dulwich Center Publications, Adelaide.

Müller, J.C., 1996, Om tot verhaal te kom - Pastorale Gesinsterapie, RGN, Pretoria.

Müller, J.C., 2000, Reis-geselskap, Lux Verbi. BM, Wellington.

Noyce, G., 1978, 'Has ministry's nerve been cut by the Pastoral Counselling movement?', Christian Century, February 1-8.

O'Leary, E., 1992, Gestalt Therapy: Theory, Practice and Research, Chapman \& Hall, London.

Outhwaite, W. \& Turner, S.P., 2007, The Sage Handbook of Social Science Methodology, Sage Publications Ltd, London.

Perls, F.S., Hefferline, R.F., Goodman, P., 1974, Gestalt therapy, excitement and growth in the human personality, Penguin Books, London.

Prochaska, J.O. \& Norcross, J.C., 2007, Systems of Psychotherapy: A Transtheoretical Analysis, Thomson Brooks/Cole, Belmont, CA.

Ridgway, J.R., 2007, 2221 Theory and Practice 1, Lecture PHD, unpublished manuscript, n.p.

Serok, S., 2000, Innovative applications of Gestalt therapy, Kriegler Publishing Compony, Malabar, FL.

Steyn, J. \& Van den Berg, J-A., 2005, "n Pastoraal-narratiewe metode om lewenshanteringsvaardighede by kankerpasiënte te identifiseer', In die Skriflig 39(4), 733-751.

Vieyra, G., 2004, Gestalt-Dialectics. Its Thesis, Anti-Thesis and Synthesis, viewed May 2011, from http://gestaltdialektik.com/

Williams, L., 2006, 'Spirituality and Gestalt: A Gestalt-Transpersonal Perspective', Gestalt Review 10(1), 6-21.

Zimmerman, J.L. \& Beaudoin, M., 2002, 'Cats under the Stars: A Narrative Story', Child and Adolescent Mental Health 7(1), 31-40. http://dx.doi.org/10.1111/14753588.00007 